Please do not remove this page

RMIT

UNIVERSITY

\title{
Engaging practices: Doing personalized media
}

Horst, Heather; Hjorth, Larissa

https://researchrepository.rmit.edu.au/esploro/outputs/9921859276501341/filesAndLinks?institution=61RMIT_INST\&index=null

Horst, H., \& Hjorth, L. (2013). Engaging practices: Doing personalized media. In The Sage Handbook of Digital Technology Research (pp. 87-101). Sage Publications.

https://researchrepository.rmit.edu.au/discovery/fulldisplay/alma9921859276501341/61RMIT_INST:Resea rchRepository

Document Version: Accepted Manuscript

Repository homepage: https://researchrepository.rmit.edu.au

(c) Heather Horst and Larissa Hjorth 2013

Downloaded On 2023/04/26 19:20:53 +1000

Please do not remove this page 
Thank you for downloading this document from the RMIT Research Repository.

The RMIT Research Repository is an open access database showcasing the research outputs of RMIT University researchers.

RMIT Research Repository http://researchbank.rmit.edu.au/

\section{Citation:}

Horst, $\mathrm{H}$ and Hjorth, L 2013, 'Engaging practices: Doing personalized media' in Sara Price, Carey Jewitt and Barry Brown (ed.) The Sage Handbook of Digital Technology Research, Sage Publications, United Kingdom, pp. 87-101.

See this record in the RMIT Research Repository at:

https://researchbank.rmit.edu.au/view/rmit:23408

Version: Accepted Manuscript

Copyright Statement: (c) Heather Horst and Larissa Hjorth 2013

Link to Published Version:

http://trove.nla.gov.au/version/202561495 


\title{
Chapter 6
}

\section{Engaging Practices: Doing Personalized Media}

\author{
Heather A. Horst and Larissa Hjorth
}

\section{INTRODUCTION}

A high-school girl updates her Facebook timeline. Two friends take a hipstamatic photo on their iPhone and upload it to their Kakao I love coffee social media game. A teenaged boy chooses skin color and clothing for his avatar on the latest Halo game. An anime (animation) music video fan selects a screensaver and changes the ringtone on her phone. A mum uses locative media settings to surreptitiously check in to see where her daughter is. A young entrepreneur types in a username from which to upload restaurant reviews on Yelp. These practices represent just a few ways in which the personalization of digital artifacts and environments has become an everyday part of life for people around the world.

Within the context of digital and social media, scholars and others approach personalization as an intimate relationship with an object or consumer item as well as a marketing strategy wherein individuals identify with a particular brand or lifestyle. The creation of an intimate relationship with an object can take place through user customization (Ito et al., 2005), the use of cultural rituals and practices (Hjorth, 2009), forms of use and repair, and other forms of engagement. Such practices transform objects 
into signifiers of identity and/or even transform the objects into part of the self. While forms of personalization have always taken place in relation to other forms of material and consumer culture and the companies or individuals who create them, digital media has enabled personalization to occur with greater speed and frequency. The ability to easily copy and paste code has given people without technical skills greater access to the tools of production, enabling users to become active users or, in Toffler's (1980) terms, prosumers (Perkel, 2008). For marketers and others operating in the era of metadata or 'Big Data' (boyd and Crawford, in press), the personalization of technologies, profile pages, avatars and other activities has become a way through which companies can create and sustain niche markets and create brand loyalty. Whereas customization often involves users choosing or controlling the content, layouts, colors and other aspects of pre-set options to reflect the users' notions of the self and identity, personalization increasingly involves the use of (predictive) algorithms that anticipate preferences and patterns of use based upon previous behaviors.

Only a decade ago, ownership of digital media and technology like mobile phones primarily conveyed status; today the personalization of digital artifacts and environments has become mundane. Personalization often takes place in 'networked public culture' - that is, in spaces where "those cultural artifacts associated with "personal" culture (like home movies, snapshots, diaries, and scrapbooks) have now entered the arena of “public” culture (like newspapers, cinema, and television)' (Russell et al., 2008). For some individuals, the decisions around personalization represent annoyances wherein opportunities to personalize artifacts and environments are at odds with the struggle to remember and manage the range of digital identities we are now forced to inhabit. 
Andrejevic (2011) and others contend that the world of digital personalization is an example of Terranova's 'social factories' whereby commercial interests are 'colonizing' narratives of personal self-presentation and sociality (Gopinath, 2005). Here, the social is not only being commodified (Andrejevic, 2011), but also simplified through a conflation with media (Lovink, 2012). For others, personalization that occurs in and through online media spaces helps to define and redefine a sense of self and community (boyd, 2011; Ellison et al., 2011; Hjorth and Kim, 2005). Such individuals view decisions around personalization as an opportunity to express themselves and the different dimensions of their personality and play with the capabilities or affordances of each device and environment.

In this chapter we explore the emergence of the 'personalization' of digital media. Drawing from disciplines ranging from anthropology, cultural studies, sociology and others, we begin this chapter by examining the ways in which personalization has been approached through different disciplinary and interdisciplinary debates. After discussing four key analytic approaches - Social Shaping of Technology (STS)/Social Construction of Technology (SCOT); Cultural Studies; Material Culture Studies; and Domestication Theory - that explicitly examine the role of media, technology and consumption in social and cultural life, we then introduce two case studies of digital environments and artifacts. The first case study explores digital environments, exploring how [personal] history and meaning is made through the possibilities and constraints of different social network site platforms. The second case study considers the implications of mobile media convergence and branding through platforms such as the iPhone by examining how these forms of mobile media personalization 'settle' (or are domesticated) into everyday life. 
Through these case studies, we reflect upon how the focus upon personalization in digital artifacts and environments returns us to classic tensions in society between agency and structure and choice and constraint, as well as new questions around the role of openness and closure (Lessig, 2001), generated vs. tethered (Zittrain, 2008) freedom and control (Chun, 2006), and customization vs standardization (Castells, 1999) in our digital worlds.

\section{APPROACHES TO PERSONALIZATION}

\section{Social Shaping of Technology (STS) and Social Construction of Technology $(\mathrm{SCOT})$}

While it is said that STS started in the 1960s, Science and Technology Studies (STS) as we know it today - what Steve Woolgar calls the 'turn to technology' - is attributed to the groundbreaking books, Social Shaping of Technology (MacKenzie and Wajcman, 1985 ) and The Social Construction of Technological Systems (Bijker et al., 1987). Within STS, there have been three main approaches - substantive, social constructivism and affordances. The substantive approach has often been associated with technological determinism or 'media effects' and has contributed to moral panics around new media like TV and video games; media scholar Marshall McLuhan's work is often described as 'media effects'. The substantive approach influenced the early development of cyberculture studies (Bell and Kennedy, 2000). Sci-fi writers like William Gibson and feminist scholars such as Donna Haraway, Sherry Turkle and N. Katherine Hayles were important in much of the imaginaries about the role of the internet and in debating the impact the internet would have on our offline lives. However, the substantive approach was criticized for its simplistic conception of technologies and users; critics argued 
that substantive approaches often negated the multi-dimensional agency of the user by ignoring the context in which the technologies/media were deployed and the myriad of ways in which the user participated in, and even ignored, the media. The model was inadequate for exploring how and why users engaged in media in complex and diverse ways.

A second approach informed by STS frameworks is the concept of 'affordances', developed by Donald Norman (1988). Affordances draws upon the principles of human-centered design and attempts to consider not only the actors'/users' physical capabilities but also their motivations, plans, values and history. Focusing upon a relational rather than subjective or essentialist position, the affordances approach seeks a more 'ecological' understanding of the ways in which media and technologies become or can be designed to become - part of users' everyday lives. The affordances approach has been widely influential in the fields of interaction design, cognitive design and human-computer interaction (HCI) that are interested in the development of practical design.

A third approach informed by STS is social constructivism, or what is often described as the Social Construction of Technology (SCOT). Early pioneers in the area of technologies, such as Raymond Williams and Judy Wajcman, influenced and informed what would become the SCOT approach that sought to move away from technological determinism. Overlaps between the work around audience and user agency in cultural studies and STS could be found at this time and informed what would become the 'participatory' model of contemporary media (Jenkins, 2006). 
As technologies have become increasingly more integral in social relations and a defining feature of the user's identity and lifestyle, so too the models in which to conceptualize the dynamic relationship between the user and their technologies have needed to become more complex. Technologies operate across various levels, encompassing both the symbolic and material, and extend existing rituals of social interaction while providing new forms of expression and media literary. As Sherry Turkle notes, 'technology serves as a Rorschach over a lifetime, a projective screen for our changing and emotionally charged commitments' (2008: 11). While scholars in STS studies were moving into a more complex understanding of the different factors shaping our understanding and use of media and technology, SCOT theorists were increasingly in conversation with cultural studies scholars in trying to comprehend the role power and identity played in media practice.

\section{Cultural Studies}

The establishment of cultural studies is largely attributed to Richard Hoggart and the Birmingham School at the Centre for Contemporary Cultural Studies (CCCS). Operating between 1964 and 1988, the Birmingham School analyzed popular culture (especially the relationship between mass media and youth subcultures), the politics of difference (gender, race and class) and hegemony (ideologies of power). While Williams and Hoggart are viewed as the key figures in this early stage of cultural studies, it was under Stuart Hall's directorship (1968-79) that cultural studies flourished. Focusing upon analyzing tacit power relationships - especially hegemony - cultural studies increasingly explored the various tensions (resistance and control) around popular and material cultures. Key texts of this period were Hebdige's Subculture: The Meaning of Style 
(1979) and Resistance through Rituals (Hall and Jefferson, 1976). Feminist scholars such as Angela McRobbie were key in highlighting the ways in which subcultures often replicated the hegemonic (and sexist) structures.

Concurrent to the work conducted by anthropologists such as Clifford Geertz and others interested in cultural texts, Stuart Hall's (1996) emphasis on encoding/decoding began to contest the 'fixed' meaning of texts in favor of interpretive models that gave agency to the reader. Extending the 'death of the author' paradigm posed by Roland Barthes, David Morley (Morley and Brundson, 1980) extended Hall's approach through his empirical case study of Nationwide; the focus upon readers'/audiences' agency represented a shift from textual analysis into what was dubbed an 'ethnographic' turn (Ang, 1985). It also contributed to the growth of fan studies and a range of other studies of the relationship between media and public/popular culture (Jenkins, 2006).

Building upon Morley's work, Paul du Gay et al.'s (1997) 'circuits of culture' approach invited researchers to map the dynamics of culture - described by the core categories of consumption, production, regulation, representation and identity - as they co-influenced one another to produce the meanings of a particular cultural object (in that case, the Sony Walkman). While the Sony Walkman case study itself is now decades old, the ongoing significance of this approach continues (Goggin, 2006). Doing Cultural Studies (du Gay et al., 1997) used an analysis of a significant technology of the time (the Sony Walkman) for dual purposes: to analyze new forms of media practice (consumption and production); and at the same time to consolidate and communicate the theoretical and methodological approaches of what was still an emerging discipline (cultural studies) 
for the benefit of students and researchers. The ongoing relevance of this work was that it captured the zeitgeist of cultural analysis in the 1990s and provided a benchmark for cultural studies research beyond that moment; Hjorth, Burgess and Richardson (2012) recently employed a 'circuit of culture' approach to the analysis of the iPhone. While the circuit of culture approach was an important moment in cultural studies, it also identified the ways in which the relationship to, and understandings of how, approaches to material culture and consumption were changing.

\section{Material Culture Studies}

Whereas cultural studies draws our attention to texts and the tensions between structure and agency, material culture studies focuses upon the processes and organizing principles behind people's engagement with things, in all of their material form. Historically situated within the museums and 'artifact' collections where objects were ordered and examined in terms of degrees of technological and thus social progress (Buchli, 2002), material culture studies developed out of British social anthropology and is characterized by interdisciplinary discussions and methods. While material culture studies projects and approaches vary, a fundamental assertion of material culture studies is its distinction from linguistic and other related forms of communication. As Tilley observes, 'material culture does not communicate meaning content in the same way as speech or phonetic script' (Tilley, 1991: 17).

As a theoretical, conceptual and methodological framework, material culture studies utilize objects as a vantage point for understanding social change and social interactions. Central to this perspective is an engagement with the specific materiality 
of the objects that acknowledges the relationality between persons and objects. In one of the seminal works of material culture studies, Miller (1987) explores the manner in which individuals, couples, families, communities or societies create or are influenced by material forms, a process called objectification. As Miller summarizes, objectification is:

A dual process by means of which a subject externalizes itself in a creative act of differentiation, and in turn reappropriates this externalization through an act which Hegel terms sublation (aufhebung). This act eliminates the separation of the subject from its creation but does not eliminate this creation itself; instead, the creation is used to enrich and develop the subject, which then transcends its earlier state. (Miller, 1987: 28)

Like Miller, Pierre Bourdieu's (1977) work on consumption highlights the processes through which culture is created and, eventually, becomes hidden from consciousness through the socialization of habits and routines, as well as the order and structures of the material and social worlds, or the habitus.

How people construct things, how things construct individuals and, in turn, how the various creations continue to change and interact over time, represent fundamental questions for contemporary material culture studies. As Victor Buchli observes, 'the processes of materialization are more significant than materiality itself and in fact variable constitutive of it - material culture itself is just a peculiar moment in these processes' (2002: 16). Igor Kopytoff's (1986) biography of the commodity demonstrates how commodities change over time and place and become alienated from the process of production (Appadurai, 1986). Understanding the processes that govern this tendency to normalize and/or re-impose normativity as rapidly as media and technology changes 
(Horst and Miller, in press), continues to represent one of the perennial questions of contemporary work on digital artifacts and environments.

\section{Domestication Theory}

The domestication approach focuses on the use and symbolic role of technologies in everyday life after their acquisition. The word 'domestication' comes from 'taming the wild animal' and this was then applied to describing the processes involved in 'domesticating ICTs' when bringing them into the home. Founded by Roger Silverstone, the British tradition of domestication theory grew out of media studies and interest in consumption studies, as well as anthropological work by Daniel Miller, Eric Hirsch and others that explored how objects become part of identity and social life. The Norwegian version integrated British approaches to domestication with conceptual frameworks from SCOT (Ling, 2004) in order to understand the evolution of mobile media and game studies, locating media within broader cultural and technological practices. The ongoing influence of the domestication approach is tied to its ability to elucidate the socio-cultural and individualistic symbolic power of commodities, especially communication technologies as an extension of older rituals and cultural practices. For example, rituals around mobile communication often involve older cultural practices like gift giving. As Silverstone and Hirsch observe in their now classic contribution to domestication theory, contemporary technological artifacts must be viewed as essentially material objects, capable of great symbolic significance, investment and meaning, while domestic technologies are 'embedded in the structures and dynamics of contemporary consumer culture' (1992: 20). 
The approach identifies new technologies as having become embedded in everyday life and household social relations (i.e. family power relations); this results in new technologies and media not only being a site (a space or context) for making meaning, but also a place in which meaning can be gleaned. In other words, objects have their own meanings that are then put into the dynamics of cultural practice, which, in turn, redefines meaning. This is why objects take on different meanings dependent upon context. While a number of critiques have emerged around the application of domestication theory outside of the home and Western contexts (Lim, 2006), domestication theory brings together the focus upon the relationship between objects or ecologies represented by SCOT, the focus upon text and meaning in cultural studies, and the focus upon logics of change and processes characteristic of material culture studies.

\section{THE PLACES OF PERSONALIZATION: CASE STUDIES}

The four perspectives introduced in the previous section shape the content, theory and analysis of the following case studies of personalization. The first case study of the domestication of social network sites draws most explicitly on material culture and domestication theory through its examination of the processes of engagement with the sites and the changes that emerge over time. Focused upon broader power relations and society shifts that shape use, the second case study integrates STS and cultural studies approaches in its exploration of iPhone users and the broader structural shifts of design personalization in mobile media platforms. In both cases we see the interplay between the affordances and capabilities of the artifacts and environment and its implications for use. Both case studies illustrate some of the tensions around conceptualizing personalization 
as a process that encompasses notions of control/freedom, empowerment/exploitation and customization/ standardization.

\section{Case Study: Aesthetics of the Self in and through Social Network Sites}

In most Western contexts, youth is a phase of life where establishing independence and a sense of autonomy from families and other institutions gives way to the influence of friends and peer groups. The creation of social network site profiles with pictures, personal details and other information is designed to connect and enhance communication between classmates, friends, family, co-workers and other acquaintances. Although the connections and interactions between participants qualitatively varies with particular websites, interests and activities, it is clear that a broad spectrum of youth and adults now participate in creating, maintaining and negotiating an expanded range of connections using these sites. Excited by the possibility of 'hanging out' with their friends in social spaces which are largely (though not exclusively) outside the purview of adults and parents (Horst et al., 2010), youth view social network sites as important tools and spaces to develop relationships with their friends and peers.

During her junior and senior years of high school, 18-year-old Ann was an active MySpace user who uploaded pictures and commented on friends' comments on a daily basis. Ann also participated in what she and her friends called 'MySpace parties', or sleepovers that involved dressing up and taking photographs to post on their respective MySpace pages. In addition to trying on clothes and posing for pictures, Ann and her friends also began to make videos of themselves doing 'funny stuff', such as dancing or imitating celebrities. While the pictures, songs, personality quizzes and other content on 
her MySpace page changed on an intermittent basis, Ann's favorite part of her page, and the most consistent feature of her MySpace page and profile, involved the incorporation of Ann's signature colors, brown and pink. As Perkel (2008) observes, copying and pasting has become a prevalent practice among those who want to personalize, customize or update and alter their social network site profiles, acts that simultaneously signal the domestication of digital media and technology.

Many of the tips or guides for changing one's profile and MySpace page (such as embedding images and videos and uploading pictures) are online - on other people's profiles, in online guides, and a range of social network sites. Describing her MySpace page, Ann notes, 'It's actually the colors of my room so it's like brown and pink. And then I don't know. I had ... a default pink so it's like what everyone sees when they see a comment'. As work in cultural studies on the relationship between consumer and popular culture and identity foregrounds, Ann's personal page mirrors the private space of her bedroom at home. The walls of her room are painted a matte chocolate brown, and the main features of her room - such as her twin-sized comforter, a large desk and a large French bulletin board - are pink. Other pink and brown accents - such as throw pillows on the bed, the ribbon on her bulletin board, the cushion on her desk chair and picture frames - have been carefully selected and arranged throughout her bedroom. For Ann, brown and pink constitute the backdrop to her daily life in both online and offline spaces.

After accepting an offer to attend a small liberal arts college, however, Ann received an invitation from her future dorm's resident assistant (RA) to participate in Facebook. Ann's RA sent her an invitation to be a member of the 'Crystal Mountain' wing, part of 
a wider network of 90 dorm residents attending her new college. Ann began spending hours at a time perusing different people's sites, looking for familiar names and faces and checking out friends of friends. As the summer progressed, Ann increasingly felt that she was becoming 'addicted' to Facebook, checking it whenever she had a free moment for status updates about four or five times per day. Through this brief, repetitive engagement, Ann started to meet the other students slated to live in her dorm, the most important and exciting of these new connections being her future roommate, Sarah.

Over the summer, Ann and Sarah sent each other short messages and comments. Some of these messages were pragmatic, such as solidifying plans to move into their dorm room, what furnishings they would be bringing or which classes they planned to take. In addition to using Facebook to communicate, Ann delved into the details of Sarah's Facebook page for insight into what she imagined would be shared interests. Decisions around what to bring to college were aligned with a desire to construct an aesthetic balance. With the aim of decorating their new dorm room, Ann and Sarah decided to upload a few pictures of their bedrooms at home onto their Facebook pages to get a sense of each other's style and tastes. Ann was excited when she looked at the photographs and saw Sarah's signature colors. 'I'm brown and pink stuff and she's brown and blue stuff!'. As scholars of material culture studies have highlighted (Young, 2005), Ann surmised that this aesthetic harmony would also signify a harmonious relationship.

Individuality is highly valued in the United States, particularly in a place like Silicon Valley where culture and competition are closely intertwined (Horst, 2009). In American society, adolescence is segmented as a particularly important time for discovering and 
expressing a sense of self that seems 'uniquely' one's own, an identity which is separate and autonomous from given social relationships, such as families, neighborhoods and communities. The locations of self-making and, in the language of Erving Goffman (1959), the 'presentation of the self' have roughly corresponded with the interplay between the front stage (public) and the back stage (private). In the age of networked public culture, the boundaries between the public and private presentations of the self are increasingly blurred.

The focus on 'face' and 'presentation' have remained central to the study of the constitution of the self and individual identity on the internet, especially the formal (and often static and textual) presentations on webpages and other online sites (Miller 1995). However, the material properties of new media and social network sites like MySpace and Facebook shape the way that these are expressed and, increasingly, the very terms and definitions of self. In addition to maintaining a collection of 'friends' (boyd, 2008; Ito et al., 2010), MySpace enabled Ann to customize the background color and font of her profile page in the same color palate as her bedroom. It was also possible to add favorite songs, videos and a range of other features. Indeed, MySpace makes it easy to 'copy and paste' html code from others' profile pages and websites in order to customize and copy the style on one's own webpage, this ability to customize ultimately undermined Ann's friends' attempts to recreate a profile after Ann's parents forced her to delete her profile after a very public case of a girl being abducted (Perkel, 2008). The ability to delete and recreate profiles thus structures a very different engagement with digital spaces. 
Ann views MySpace and Facebook as places where the physical and material -relationships, tastes and connections - are reaffirmed. For Ann, MySpace and Facebook are tangible spaces where she establishes and asserts her sense of self. In a consumer culture like the United States, Ann essentially constructs herself as different configurations of pre-determined selections (customization) within the generally acceptable genres of her peers, a person who likes pink and brown, someone who likes a particular kind of music, and someone who maintains a balance and order in all the 'environments' she inhabits. And like many American teenagers, her sense of self in the world hinges upon asserting a material presence in these different environments.

Ann's aesthetic is based on the balance and continuity between a variety of key relationships. These may be objects, persons or places. In many ways Ann uses her roommate as a critical background relationship for her Facebook profile, in much the same fashion she used her bedroom as the critical background relationship for her MySpace profile. The social network sites where Ann chooses to participate extend the mirror in which she comes to see herself and gain a sense of who she might be (Miller, 1995; Robinson, 2007; Strathern, 2004). Youth like Ann create order in and through the construction, alteration and appropriation of their interconnected media worlds. For Ann, and many individuals like her, social network sites such as MySpace and Facebook play or have played an important role in structuring and sustaining social worlds, including Ann's ability to imagine her future college life in the dorm and establish relationships with new individuals and communities. Social network sites also provide Ann with opportunities to understand and assert her own sense of who she is and who she might become in the transition from high school to college through spaces of networked public 
culture.

\section{Case Study: Mobile Media as Personalization Par Excellence}

The mobile phone is one of the most intimate devices today (Fortunati, 2002; Lasén, 2004), a repository for the personal (Bull, 2007). Personalization as a process is harnessed by industry as well as the practices of the user - epitomized by user created content (UCC). In each location, the practices of personalization differ, highlighting the growing importance of place in shaping networked and mobile media. Far from eroding the importance of place, mobile media amplify a sense of locality and belonging. As mobile media moves into the undulating terrain of smart phones we see tensions around open and closed systems coming to the fore (Goggin, 2012). On the one hand, smart phones like iPhones afford users new applications and convergent platforms to create content and develop 'vernacular creativity' (Burgess, 2009). On the other hand, with the rise of big data - that is, users' profiles taken by companies like Google and sold to marketers - media personalization may become little more than a node in the social factory of capitalism (Andrejevic, 2011).

The iPhone, with its motto of 'it's not a phone, it's a platform' (Grossman, 2007), epitomizes contemporary debates and tensions over contemporary forms of personalization. The escalation of the iPhone's popularity has been very much due to the ability to customize applications. Paralleling the customization of Japan's i-mode, the iPhone's success has been contingent upon applications, and in particular the way in which Apple has managed to re-brand personalization to such an extent it seems to be an Apple invention. Yet, the personalization of technology occurred long before 
mobile media and the iPhone phenomenon. Indeed, countries such as Japan have excelled globally in their ability to spearhead the 'personal technologies' revolution from the Sony Walkman onwards. Clearly signposting her SCOT lineage, Ito (2005), for example, argues that it is the notion of the 'personal', along with the pedestrian and portable, that has characterized Japanese technologies for decades. Indeed, part of Apple's success results from their deployment of high-level personalization, particularly apparent in what anthropologist Brian McVeigh (2000) has called 'techno-cute' which makes the coldness of new technologies 'warm' and 'friendly'. Personalization continues to be about domesticating, locating and humanizing new technologies; it is this ongoing and localized practice that is indicative of the tension between users and industry as personal technologies increasingly become public.

The closed platform world offered by the iPhone notably borrows from its precursor, the i-mode in Japan. Sawhney describes this paradox of personalization in the iPhone's precursor - a tension between user creativity (i.e. UCC) and openness, and industry's commercializing of personalization in the form of applications - as a gated community version of the internet. Moreover, whereas Zittrain (2008) contends that the iPhone is part of a constellation of devices he calls 'tethered applications', Goggin (2011) argues that 'tethered devices' fail to be generative platforms because they are configured to be actively inimical to user experimentation and co-creation. For Goggin, part of this shift lies in the way in which Apple managed to brand the smart phone evolution into an Apple revolution. As he notes:

Perhaps what most distinguished the iPhone from many other adaptations of cell phones was its rapturous reception, and, hand-in-hand with this, Apple's 
phenomenally successful marketing campaign. Herein lies the paradox of adaptation that the iPhone represents. The iPhone is clearly an adaptation of the cell phone. As Wired magazine's Geekipedia points out, the iPhone is an obvious descendant of the smartphone - the multimedia cell pone that combines various computer programs with entertainment options. Yet the 'biggest launch since the Apollo' rebadges this evolution as a revolution ... (Goggin, 2011: 142)

The paradoxes surrounding this re-purposing and relocation of the mobile media evolution into the iPhone revolution is perhaps best understood by moving beyond media images and rhetoric to the personalization practices of everyday users. For example, can we say there is such a thing as an iPhone affect? What are the realities of personalization practice beyond the initial excitement of 'newness' and novelity?

Given that our first case study explored the world of a young women's rites of passage vis-à-vis social media, in this second case study we reflect upon women's experiences of mobile media personalization and its relationship to work and family life. While our first case study considered personalization in relationship to a young person's identity formation, this case study reveals the multi-generational character of personalization practices through an analysis of surveys and interviews among users in Melbourne, Australia between 2009 and 2010. Focused upon the relationship between personalization and affect, the study revealed that mobile media practice is a highly gendered activity (Fortunati, 2009; Hjorth, 2009). Indeed, where personalization was concerned, women seemed to be most vocal in discussing the struggles between work and leisure, home and public - what Gregg (2011) has called 'presence bleed'. In the study, iPhone users spoke in detail about the apps that seemed to create tensions around control and freedom, 
customization and standardization. However, despite the initial downloading of a plethora of apps, many of the respondents noted a decline in use after the 'honeymoon' was over.

In order to understand iPhone perceptions and practices after the honeymoon phrase, we surveyed users after they had initially bought the iPhone and the types of media practice they participated in, and then again one year later, to see how these practices had been domesticated (or not) into the users' lives. This surveying occurred when the iPhone 3 was first introduced in 2009 and then again, around the time of the iPhone 4 launch in 2010. For this study we surveyed 40 women of varying ages and across different socioeconomic and cultural backgrounds in Australia. One of the first things that became apparent was the fact that many respondents either had IT experience or viewed new media as both necessary for work or as a hobby. This media literacy phenomenon is not the impact of the iPhone per se, but highlights how the timing of the iPhone can be viewed as part of a broader new media landscape in which women's labor and creativity feature. As Fortunati (2009) has observed, there needs to be more studies of gender gradations, especially in terms of age and class, to understand the role of gendered mobile media practice. In addition, we see how the phone has become the multimedia device akin to a miniature caravan which houses all one's personal details, much like the function of one's home as a symbol for domesticity, privacy and family. While this 'caravan' affords much mobility, its symbolic weight, and wait (i.e. the temporality), operates as a perpetual reminder of the various tasks and work in need of doing. This phenomenon has been called many things, including the 'wireless leash' (Qiu, 2008) whereby the mobile sets us free at the same time as it creates more limits. For example, one is 'free' to roam but also available. But this miniature caravan also reveals people's 
increasing proclivity towards working at home. Just as the intimate goes public, the public - and especially work - goes private.

The tensions between the pros and cons surrounding mobile intimacy - that is, the overlay of the physical, geographic and electronic with the social, emotional and cultural - are amplified in the case of working mothers. For working mothers, the tethering of the phone to the domestic is clear - symbolized by the always-on mothering feature that Matsuda has aptly called 'mum in the pocket' (2009). As Lim (2006) identifies in the case of mainland Chinese parents, many see technologies like mobile media as not only important for their children's education but also a way in which to keep a perpetual eye on them. Indeed, the levels and layers of tethering (that often pull) afforded through the so-called mobility of mobile media come at a price. Given that many women negotiate mothering along with paid work, there is a tension between mobile media decreasing yet also adding to the daily workload. Not only is the miniature caravan an embodiment of domestic labor and tethering to home, it is also about the home office. Gregg's (2011) notions of 'work's intimacy' and the 'presence bleed' highlights how workers struggle to differentiate between work and leisure time and spaces in light of the presence of online and social media. Despite initially downloading many 'cool' apps about creativity (i.e. photo apps like Hipstamatic), play (standard puzzle or simple games like Angry Birds and haptic games like Balloonimals), socializing (Facebook, Twitter, Foursquare) and lifestyle, it was often the basic work tasks like answering and writing e-mails and surfing the internet that featured in respondents' usage. In short, their usage of the iPhone demonstrates no clear 'iPhone affect'. 
One of the key features that emerged was the difference in personalization practices between those who had and didn't have children. This quality played out across a variety of personalization practices, from respondents' creativity and UCC to the types of affordances and applications used. For this discussion we focus upon a few of the female respondents who were working, some of whom had children and some of whom did not, and either worked in or had immense interest in the area of new media. The need to create clearly defined boundaries between work and life was something that the respondents grappled with as work and intimacy became increasingly mobile and performed both at home and away. On the one hand, the iPhone functioned as a welldesigned mobile with internet, allowing them to be connected to work whilst at home. On the other hand, this flexibility also meant that many felt the pressure to always be 'on' and in work mode whilst also doing domestic work. For Zoe, like other respondents, the main use of the iPhone was e-mails and internet on the run. Whilst she had initially starting using the calendar she stopped after a few weeks and reverted back to the old mode of writing on paper, noting that the multimedia capacity of the iPhone was 'probably wasted on me'. Viewing the iPhone as fun, useful and about connectivity, she described the iPhone as just a 'glorified iPod'.

For women who had children, the role of media such as iPhones clearly helped to forge work/home fusions in what was an already highly multitasking environment. Many of these women did a lot of their work from home (so that they could effectively do at least two jobs: looking after the children and working), demonstrating the role of personal technologies in not only outsourcing domestication outside the physical home but also bringing work back into the home. The iPhone could be seen to be part of the 
casualization of labor whereby work becomes and is squeezed into micro-moments between other activities in the home. Being a repository for, rather than a cause of, these work/home fusions, the iPhone highlights how being 'always on' comes at a cost (Gregg, 2011; Wajcman et al., 2009). Just as mobile technologies set us free to roam wherever we wish, they also create new types of restrictions, whereby one is always on call, and impact upon the types of co-presence (being simultaneously here and there, online and offline) we participate in as the personal and intimate fuses with the public, and work bleeds into the private. Indeed, mobile media personalization highlights many of the paradoxes within contemporary life.

\section{CONCLUSION: PERSONALIZATION，'PRODUSERS', PRIVATIZATION AND BEYOND}

In this chapter we have discussed the genealogy of digital media personalization through various disciplinary trajectories. In the first case study, we explored the interplay between the capabilities and affordance of social network sites (the ability to personalize user profiles, the capacity to upload pictures and the use of the site as a platform for other activities), the motivations for youth to use social network sites (e.g. to create and maintain friendships, share information and present oneself) and the broader identity work that teenagers in the US and other Western contexts often engage in as part of the process of coming of age. Through the case study of mobile media we highlighted some of the ways in which personalization is an unavoidable and deeply paradoxical experience that reflects broader socio-cultural inflections about control and freedom (Chun, 2006). Mobile media as digital artifacts are repositories for, and of, intimacy 
by reflecting the user's relationships and communication patterns with others. In this section we draw from a case study of the iPhone and the role of applications (apps). Apps represent industry-generated rather than user-created personalization.

According to Campbell and Park, the shift towards a new 'personal communication society' can be 'evidenced by several key areas of social change, including symbolic meaning of the technology, new forms of coordination and social networking, personalization of public spaces, and the mobile youth culture' (2008: 371). Digital media environments and mobile media spur us to reconsider approaches such as domestication, given the increasing collapsing boundaries between a definitive space called 'home' and the artifacts and environments which accompany us throughout the day. As Morley (2003) suggests, various artifacts and environments provide the capacity to tether the user to notions of the home at various levels: emotional, social, and psychological, to name a few.

Just as intimacy has become public in and through networked public culture, so too has the notion of the personal taken on new cartographies. In the first case study, we focused upon how youth construct a sense of order in and through digital environments and the interplay between these new media and their relationships with places, persons and objects. We further revealed the ways in which these media spaces suggest an act of self-construction that is highly social, but also constrained, whereby individuality emerges through the ordering and configuring of space in relation to peers and parents. What is significant is not the degree of individualism Ann exhibits, but the ways in which Ann and other individuals exist in alignment with highly socialized media of expression. 
This is perhaps even more evident with social network sites, which enable youth to make public the bedroom, a space often viewed as a highly privatized and personal domain. This case study also highlights how the idea of the domestic - through the conflation between domestic and personal technologies - has becoming increasingly mobile across technological, geographic and socio-economic terrains. In turn, this requires a reworking of such approaches as the domestication theory, given that the dynamism of the home is now increasingly pervasive outside the physical space of the home, leading many to suggest that 'home' may be as much a social network site or mobile phone as it is a physical location with a street address.

The personalization of media also reflects broader debates about user agency and the increasing commodification of data. As the second case study revealed, underlying the so-called user-centered content (UCC) revolution has been the fact that the data is then mined and sold to advertisers (Lovink, 2012; Vaidhyanathan, 2011). This has led some, like Andrejevic to argue that, 'social networking sites don't publicize community, they privatize it' (Andrejevic, 2011: 97). While Andrejevic sees the personalization of media as part of users' creative, social and emotional labor that are exploited by corporations for financial gain, Humphreys and Banks (2008) view online game users/players as co-creators. Extending Toffler's concept of prosumers, wherein consumers start to take on elements of the production for free (i.e. filling their own petrol tanks), Bruns (2006) utilizes the term 'produsers' to describe the phenomenon of producing users. This debate around the exploitation and empowerment elements of online media today is only going to amplify with the increasing integration of 'Big Data' into our everyday lives. Increasingly, questions about agency, power and labor continue to haunt the field 
as it moves unevenly into convergent social, locative and mobile media terrains. As personalization migrates across different platforms, contexts and media, its cartographies become more political in their expression of inner capitalist paradoxes. Whether it is empowerment vs exploitation, control vs freedom or customization vs standardization, personalization in an age of data mining has become a vexed issue that is as ubiquitous as it is ambiguous.

\section{SUGGESTIONS FOR FURTHER READING}

Hinton, S. and L. Hjorth (2013) Understanding Social Media. London: Sage.

Hjorth, L. (2009) Mobile Media in the Asia-Pacific: Gender and the Art of Being Mobile. London: Routledge.

Horst, H. and Miller, D. (eds) (2012) Digital Anthropology. Oxford: Berg.

Gerard, G. (2011) Global Mobile Media. London: Routledge.

Ito, M., et al. (2010) Hanging Out, Messing Around and Geeking Out. Cambridge, MA: MIT Press, http://mitpress.mit.edu/books/hanging-out-messing-aroundand-geeking-out

Perkel, D. (2008) 'Copy and Paste Literacy? Literacy Practices in the Production of a MySpace Profile', in K. Drotner, H.S. Jensen and K. Schroeder (eds), Informal Learning and Digital Media: Constructions, Contexts, Consequences. Newcastle, UK: Cambridge Scholars Press.

Papacharissi, Z. (ed.) (2010) A Networked Self: Identity, Community, and Culture on Social Network Sites. London: Routledge.

\section{REFERENCES}


Andrejevic, M. (2011) 'Social Network Exploitation', in Z. Papacharissi (ed.), A Networked Self: Identity, Community, and Culture on Social Network Sites. London: Routledge, 82-101.

Ang, I. (1985) Watching Dallas:: Soap Opera and the Melodramatic Imagination $\square$. London: Routledge.

Bell, D. and Kennedy, B. (eds) (2000) The Cyberculture Reader. London: Routledge.

Berlant, L. (1998) 'Intimacy: A Special Issue', Critical Inquiry, 24/2: 281-88.

Bijker, W., Hughes, T. and Pinch, T. (eds) (1987) The Social Construction of Technological Systems: New Directions in the Sociology and History of Technology. Cambridge: MIT Press.

Bloustein, G. (2003) Girl Making: A Cross-Cultural Ethnography on the Processes of Growing Up Female. New York: Berghahn Books.

Bourdieu, P. (1977) Outline of a Theory of Practice. Translated Richard Nice.

Cambridge: Cambridge University Press.

Bovill, M and Livingstone, S. (2001) 'Bedroom Culture and the Privatization of Media Use', in Children and Their Changing Media Environment: A European Comparative Study. Mahwah, NJ: Lawrence Erlbaum Associates, pp. 179200.

boyd, d. (2008) 'Why Youth (Heart) Social Network Sites: The Role of Networked Publics in Teenage Social Life', in D. Buckingham (ed.) Youth, Identity, and Digital Media. John D. and Catherine T. MacArthur Foundation Series on Digital Media and Learning. Cambridge, MA: MIT Press, pp. $119-42$

boyd, d. (2009) 'Friendship', in Ito, et al. (eds) Hanging Out, Messing Around and Geeking Out: Living and Learning with New Media. Cambridge: MIT Press. 
boyd, d. and Ellison, N. (2007) 'Social Network Sites: Definition, History, and

Scholarship', Journal of Computer-Mediated Communication, 13(1), http:/ /jcmc.indiana.edu/vol13/issue1/boyd.ellison.html

boyd, d. and Crawford, K. (in press) 'Critical Questions for Big Data: Provocations for a Cultural, Technological, and Scholarly Phenomenon', Information, Communication, \& Society.

Bruns, A. (2005) 'Some Exploratory Notes on Produsers and Produsage', snurblog, 3 November 2005, http://snurb.info/index.php?q=node/329

Buchli, V. (2002) The Material Culture Reader. London: Berg.

Bull, M. (2007) Sound Moves. iPod Culture and Urban Experience. London: Routledge.

Burgess, J. (2008) “"All Your Chocolate Rain Are Belong to Us”? Viral Video, YouTube and the Dynamics of Participatory Culture', in G. Lovink et al. (eds), The Video Vortex Reader. Amsterdam: Institute of Network Cultures.

Campbell, S. and Park, Y. (2008) 'Social Implications of Mobile Telephony: The Rise of Personal Communication Society', Sociology Compass, 2(2): 371-87.

Cassell, J. and Cramer, M. (2008) 'High Tech or High Risk: Moral Panics about Girls Online', in T. McPherson's (ed.), Digital Youth, Innovation, and the Unexpected. The John D. and Catherine T. MacArthur Foundation Series on Digital Media and Learning. Cambridge: MIT Press, pp. 53-76.

Castells, M. (1999) The Rise of The Networked Society. Cambridge, MA: Oxford University Press.

Chun, W. (2006) Control and Freedom. Cambridge: MIT Press.

Du Gay, P., Hall, S., Janes, L., Mackay, H. and Negus, K. (eds) (1997) Doing Cultural Studies: The Story of the Walkman. London: Sage. 
Fortunati, L. (2002) 'Italy: Stereotypes, True And False', in J.E. Katz and M. Aakhus (eds), Perpetual Contact: Mobile Communications, Private Talk, Public Performance, Cambridge: Cambridge University Press. pp. 42-62.

Fortunati, L. (2008) 'Gender and the Mobile Phone', in G. Goggin and L. Hjorth (eds) Mobile Technologies. London: Routledge, pp. 23-35.

Gerard, G. (2011) Global Mobile Media. London: Routledge.

Goffman, E. (1959) The Presentation of Self in Everyday Life. New York: Anchor Books.

Goggin, G. (2006) Cell Phone Culture: Mobile Technology in Everyday Life. London: Routledge.

Gopinath, S. (2005) 'Ringtones, or the Auditory Logic of Globalization', First Monday 10(12) (December), http://firstmonday.org/htbin/cgiwrap/bin/ojs/ index.php/fm/article/view/1295/1215

Gregg, M. (2011) Work's Intimacy. London: Polity Press.

Grossman, L. (2007) 'Invention of the Year: The iPhone', Time, http://www.time.com/ time/specials/2007/article/0,28804,1677329_1678542,00.html (accessed 1 December 2008).

Hall, S. (1996) [1973] Encoding/Decoding. In P. Marris and S. Thornham (eds), Media Studies: A Reader. Edinburgh: Edinburgh University Press.

Hall, S. and Jefferson, T. (eds) (1976. Resistance through Rituals. London: Routledge. Hebdige, D. (1979) Subculture: The Meaning of Style. London: Metheun.

Hjorth, L. (2009) Mobile Media in the Asia-Pacific: Gender and the Art of Being Mobile. London: Routledge. 
Hjorth, L., Burgess, J. and Richardson, I. (eds.) (2012) Studying Mobile Media:

Cultural Technologies, Mobile Communication, and the iPhone. London: Routledge.

Horst, H. (2009) 'Aesthetics of the Self: Digital Mediations', in D. Miller (ed.), Anthropology and the Individual. Oxford: Berg, pp. 99-113.

Horst, H. and Miller, D. (eds) (2012) Digital Anthropology. London: Berg.

Humphreys, S. and Banks, J. (2008) 'The Labour of User Co-Creators', Convergence 14(4): 401-18.

Ito, M. (2005) 'Introduction: Personal, Portable, Pedestrian', in M. Ito, D. Okabe and M. Matsuda (eds), Personal, Portable, Pedestrian: Mobile Phones in Japanese Life. Cambridge, MA: MIT Press, pp. 1-16.

Ito, M., Matsuda, M. and Okabe, D. (eds) (2005) Personal, Portable, Pedestrian: Mobile Phones in Japanese Life. Cambridge, MA: MIT Press.

Jenkins, H. (2006) Fans, Bloggers, and Gamers: Essays on Participatory Culture. New York: New York University Press.

Kopytoff, I. (1986) 'The Cultural Biography of Things: Commoditization as Process', in A. Appadurai (ed.), The Social Life of Things: Commodities in Cultural Perspective, Cambridge: Cambridge University Press, pp. 64-91.

Lasén, A. (2004) 'Affective Technologies - Emotions and Mobile

Phones', Receiver, 11, http://www.academia.edu/472410/ Affective_Technologies._Emotions_and_Mobile_Phones

Lessig, L. (2001) The Future of Ideas. New York: Random House.

Lim, S. (2006) 'From Cultural to Information Revolution. ICT Domestication by MiddleClass Chinese Families', in T. Berker, M. Hartmann, Y. Punie and K. Ward (eds), Domestication of Media and Technology. Maidenhead, UK: 
McGraw-Hill International, pp 185-201.

Lovink, G. (2012) Networks Without a Cause. London: Polity.

MacKenzie, D. and Wajcman J. (eds.) (1999) The Social Shaping of Technology: How the Refrigerator Got Its Hum. Milton Keynes: Open University Press.

McRobbie, A. and Garber, J. ([1978] 2000) 'Girls and Subcultures', in A. McRobbie (ed.), Feminism and Youth Subcultures, 2nd edn. London, UK: Routledge, pp. 12-25.

McVeigh, B. (2000) 'How Hello Kitty Commodifies the Cute, Cool and Camp:

"Consumutopia" versus "Control” in Japan', Journal of Material Culture, 5(2): 291-312.

Matsuda, M. (2009) 'Mobile Media and the Transformation of Family', in G. Goggin and L. Hjorth (eds), Mobile Technologies: From Telecommunications to Media. New York: Routledge, pp. 62-72.

Mazzarella, S. (2005) 'Claiming a Space’, in. S. Mazarella (ed.), Girl Wide Web. New York: Peter Lang Publishing, pp. 141-60.

Miller, D. (1987) Material Culture and Mass Consumption. London: Blackwell.

Miller, H.W. (1995) 'Goffman on the Internet: The Presentation of Self in Electronic Life'. Paper presented at the Embodied Knowledge and Virtual Space Conference, http://www.dourish.com/classes/ics234cw04/miller2.pdf

Morley, D. (2003) 'What's "Home" Got To Do With It?', European Journal of Cultural Studies, 6(4): 435-58.

Morley, D. and Brundson, C. (1980) The Nationwide Television Studies. London: Routledge.

Norman, D. (1988) The Design of Everyday Things. London: Basic Books. 
Pascoe, C.J. (2009) 'Intimacy', in M. Ito et al. (eds), Hanging Out, Messing Around and Geeking Out: Living and Learning with New Media. Cambridge, MA: MIT Press.

Perkel, D. (2008) 'Copy and Paste Literacy? Literacy Practices in the Production of a MySpace Profile', in K. Drotner, H.S. Jensen and K. Schroeder (eds), Informal Learning and Digital Media: Constructions, Contexts, Consequences. Newcastle, UK: Cambridge Scholars Press.

Qiu, J. (2007) 'The Wireless Leash: Mobile Messaging Service as a Means of Control', International Journal of Communication, 1: 74-91.

Robinson, L. (2007) 'The Cyberself: The Self-ing Project Goes Online, Symbolic Interaction in the Digital Age', New Media and Society, 9(1): 93-110.

Russell, A., Ito, M., Richmond, T. and Tuters, M. (2008) 'Culture: Networked Public Culture', in K. Varnelis (ed.), Networked Publics. Cambridge, MA: MIT Press.

Sawhney, H. (2004) 'Mobile Communication: New Technologies and Old Archetypes', in A. Lin (ed.), Proceedings of the Mobile Communication and Asian Modernities I, City University of Hong Kong, June.

Silverstone, R. and Haddon, L. (1996) 'Design and Domestication of Information and Communication Technologies: Technical Change and Everyday Life', in R. Silverstone and R. Mansell (eds), Communication by Design: The Politics of Information and Communication Technologies. Oxford: Oxford University Press, pp. 44-74.

Silverstone, R. and Hirsch, E. (eds) (1992) Consuming Technologies: Media and Information in Domestic Spaces. London: Routledge.

Strathern, M. (2004) 'The Whole Person and Its Artifacts', Annual Review of Anthropology, 33: 1-19. 
Tilley, C. (1991) Material Culture and Text. London: Routledge.

Toffler, A. (1980) The Third Wave. New York: Bantam Books.

Turkle, S. (ed.) (2008) The Inner History of Devices. Cambridge, MA: MIT Press.

Vaidhyanathan, S. (2011) The Googlization of Everything. Berkeley: University of California Press.

Varnelis, K. (ed.) (2008) Networked Publics. Cambridge, MA: MIT Press.

Wajcman, J., Bittman, M. and Brown, J. (2009) 'Intimate Connections: The Impact of the Mobile Phone on Work/Life Boundaries', in G. Goggin and L. Hjorth (eds), Mobile Technologies: From Telecommunications to Media. New York: Routledge, pp 9-22.

Woodward, S. (2005) 'Looking Good, Feeling Right: Aesthetics of the Self', in S. Kuechler and D. Miller (eds), Clothing as Material Culture. Oxford: Berg.

Young, D. (2005) 'The Colours of Things', in P. Spyer, C. Tilley, S. Kuechler and W. Keane (eds), Handbook of Material Culture. Thousand Oaks, CA: Sage Publications.

Zittrain, J. (2008) The Future of the Internet - and How to Stop It. New Haven: Yale University Press. 